\title{
Assessment of the state of worldwide-used intellectual property in the industry specialized design activities
}

\author{
Monika Rakova ${ }^{1, *}$ \\ ${ }^{1}$ University of Economics, Faculty of Business Management, Dolnozemska cesta 1, 85235 Bratislava, \\ Slovakia
}

\begin{abstract}
Research background: The cultural and creative industries are one of the main drivers of the economy throughout the European Union. There is a strong competition in the creation of creative products or services. Current protection of the creation of given products and services helps to prevent mistakes that can often have liquidating consequences for artists. There is a lot of competitive pressure on social networks. It is therefore necessary for these artists to be made aware of the protection of their work, in which they have invested their time, funds and efficiency with regard to the protection of intellectual property to gain a very important role in their industry.

Purpose of the article: The main purpose is to point out the use of intellectual industry rights in a selected branch of the creative industry - in the sector of specialized design activities based on questionnaire survey realized at first half of this year.

Methods: The basic methods that were used in the processing of the paper include generally applied methods such as analysis, synthesis, induction or deduction. In the application part of the presented paper, we used the results of a questionnaire survey among companies operating in the field of specialized design activities.

Findings \& Value added: As the added value can be considered the assessment of the state of worldwide-used intellectual property protection among companies in the selected sector of the creative industry, which was significantly affected by pandemic Covid-19. Another conclusion is the proposal of possible solutions to increase the protection of their intellectual activity.
\end{abstract}

Keywords: creative industry; intellectual property; protection

JEL Classification: $\mathrm{H} 81$; O30; $O 31$

\footnotetext{
*Corresponding author: monika.rakova@euba.sk
} 


\section{Introduction}

The present time we live in is stimulating creativity. We encounter the term "creativity" at work, at school, on the street, but also in a virtual environment. In recent years, creativity has become as important a factor of production as capital or human labour. The report on the state and potential of the creative industry in Slovakia says that the cultural and creative industry is one of the main driving forces of the economy throughout the European Union. It creates new jobs, stimulates innovation, adds value and serves as an effective tool for social cohesion. Cultural and creative industries contribute to the preservation of cultural, historical and architectural heritage. Today, the cultural and creative industries face many challenges such as the digital market, internet piracy and the economic impact of a pandemic Covid-19. (Ministry of Culture of Slovak republic, 2013) Intellectual property is an intangible asset. It is the result of creative thinking or creative mental activity and can be perceived through the senses. It is subject to legal protection and its use is, therefore, subject to the consent of the author or creator. (Obnova Európy, 2021) Intellectual property protection is an important aspect of the creative industry.

\subsection{Meaning of intellectual property rights in global view}

Creativity and innovation define major events in the history of mankind. Nowadays, it is particularly striking that new technologies have a substantial effect on the agenda of the civilization. Historically, keeping up with the fast pace of creative and innovative progress was supported by the precise reformation of intellectual property law. Intellectual property was formed as an internationally recognized term in 1967, after adoption of the Convention for the Establishment of the Intellectual Property Organization, a terminological definition of intellectual property. The rights are performed only when the legislation has a strong protective level to ensure the enforcement of legal norms. (Taliashvili and Shamatava, 2020) The objects of intellectual property rights, noting that, as in any activity where there is an element of creativity. (Kharytonov, 2021) intellectual property is results from innovations based on the previously existing knowledge, a great number of inventions is actually the result of creational improvements of previous work, or the result of new creative expressions of old ideas and constructs. The COVID-19 pandemic has re-emphasised the importance of access to intellectual property during a crisis. This is especially true in two key areas: public health, and educational and cultural engagement. Although this involves two distinct areas of intellectual property rights with differing access barriers - patent and copyright - the common underlying link is their complex relationship with access in the public interest. (Walsh et al., 2021) Due to Covid-19, the availability of information of the already existing solutions, the level of development of science and technique is of fundamental significance for researchers. (Lukinović and Vitošević, 2021) In particular, copyright protects the creative intellectual activity of the author and allows the author to have personal rights, e.g. the right to state his name and property rights e.g. the right to give consent to make a photocopy. The author of the author's work is one natural person or several natural persons. The subject of copyright may also include a legal entity. Copyright is created automatically after the creation of the author's work. The work does not have to contain any copyright symbol as a condition of protection, nor does it have to register with the relevant authority. It is necessary that the result of creative activity is perceptible by the senses and is expressed externally. (Majduchova, 2019) Copyright plays a key role in the creative industries. These rights protect creative works produced in individual branches of the creative industry. They allow owners of works to coordinate and control the use of their works, and even allow third parties to reproduce their works. The role of copyright is to reward the creativity and creative thinking of creators. It is often the case that copying and downloading from the Internet take place 
free of charge in the creative industries. For example, during the pandemic, audiovisual piracy increased by more than 33\%. (Industrial Property Office of The Slovak Republic, 2020) Our paper is focused on the second group of intellectual rights - industry rigts, so it is important to define the relation between property rights and creativity. If property rights allow the allocation of the majority of standard industrial goods without any special difficulty, however, when they are applied to creative goods, new problems arise. Then, for us, the persistence of a low system of intellectual property rights in the design industry does not mainly derive from its efficiency but from the characteristics of the inputs that are used in the creative production process. They constitute strong constraints for defining, entitling, legitimating, enforcing, valuating and exchanging property rights. Thus, the different economic actors develop different kinds of strategic behavior in order to obtain earnings and can try to protect copyrights, trademarks, new assets, old assets (heritage), private or collective assets, and so on. The institutional characteristics of this specific industry-such as the models of management, the type of ownership, the size of the firms, aEuro broken vertical bar lead to different historical models of management through intellectual property rights. (Barrère and Delabruyère, 2011).

\subsection{The basis of creative and cultural industries}

Cultural and creative industries are now an established area of academic research. Yet, the welcome innovations that are associated with the development of a new field of study are also matched by confusions and conjectures. The term itself, 'cultural and creative industries', is the subject of extensive debate. (Casey and O'brien, 2020) The digital environment as well as actual difficult pandemic situation has dramatically affected creative industries in all kinds of ways, requiring dramatic changes in all parts of the value chain, including business models, stakeholder relationships and intellectual property management. (Snowball et al., 2021) Definition of the activities falling within Cultural and Creative sector is not an easy operation because of it is rapidly evolving and also strongly influenced by technology and by the processes leading to content and products All around the world, the CCs is a major and growing part of the global economy. Its importance as a generator of jobs and wealth is increasingly recognized. (Imperiale et al., 2021). Creative industries are cross-sectoral and therefore belong to the future emerging industries. They intend to capture new development potential to be deployed in the future. (Gerlitz and Prause, 2021) Work in the creative economy has been described as 'effective labour', which refers to the 'immaterial labour' typical for so many service industries that is based on relationships and incites feelings of wellbeing, connectedness, passion and excitement. Many workers in the creative and cultural industry experience a strong affective attachment to arts and culture, and at times also a 'fan experience'. (Skujinia, and Loots, 2020). Our paper focus onto one sector of creative and cultural industries - selected branch of specialized design activities. This includes following activities:

- Fashion design relating to textiles, clothing, footwear, jewelery, furniture and other fashion goods,

- Industrial design,

- Activities of graphic designers and

- Activities of interior decorators.

The most important component is the fashion industry, which is connected with the textile industry and has a long tradition also, but just not only, in Slovakia. The fashion industry consists of textile design, footwear design and accessories. The fashion industry includes designers, textile and clothing manufacturers and sales networks. Industrial design, which is connected with product and spatial design and solves the design of products for everyday life from cutlery to the automotive industry. Graphic design is a kind of visual communication 
art and combines graphic elements with texts. Artistic graphic design proposals are created to order for a specific purpose of advertising a given product, service or to make a specific organization visible. The results of the creative intellectual activity of a graphic designer are advertisements, posters, leaflets, typography of books or magazines, web site design, design manuals or advertising campaigns. The main task of interior decorators is to furnish interiors and exteriors with furniture and accessories. Currently, the activity is in demand by the real estate market. Interior decorators will adjust the property for sale so that it is aesthetically very attractive for a potential buyer. (European Commission, 2020)

\section{Methods}

As is written, paper is focused just to one branch - branch of specialized design activities. In this paper, there are used many general methods such as analyse, synthase and deduction. Practical part of paper is based from questionaries' which were send at the beginning of 2021 year among selected companies from branch of specialized design activities. The questionnaire consisted of thirteen questions, which were purposefully asked to map the current state of intellectual property protection in the sector - Specialized design activities. Using individual questions, we identified what is the practice in intellectual property protection in the field of specialized design activities, what possibilities of intellectual property protection are used by the design companies, what problems they encountered in implementing protection of their creation and what benefits they expect in protecting their original products. The first part of the questions contained in particular the general characteristics of individual companies focused on the activity of the business, the number of employees, the length of operation on the market and the registered office. The second part of the questions was more about the issue. Due to the limited scope of the paper, we will use only part of the information obtained.

\section{Results and Discussions}

In the following part of the article we will focus on mapping the situation in companies in the sector of specialized design activities. The total number of companies contacted was at the level of 300 , but only 50 of them sent us answers to the questions.

The first question we identified what is the main activity of the companies. It follows from the above answers that $38.8 \%$ of companies do business in fashion design or design clothing, jewellery, footwear or furniture. The second largest group are companies that implement graphic design, approximately $32 \%$. Results are shown at figure 1 .

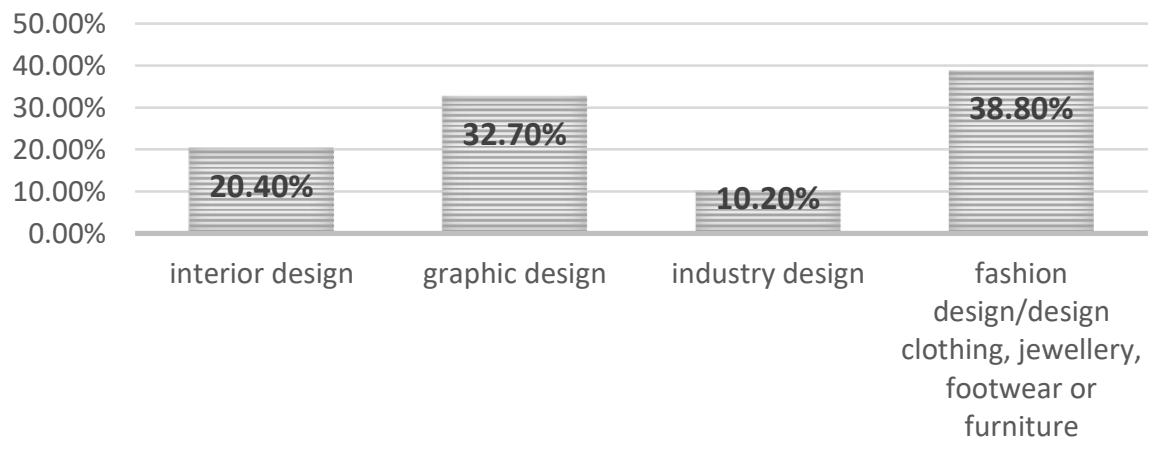

Figure 1. The main business of the addressed companies

Source: Own research 
The second question we found out what is the number of employees in each company. More than $83 \%$ of companies have less than 10 employees. It follows from the above fact that micro-enterprises predominate in this sector, where the owner is also an employee and at the same time manages the entire operation of the company. We did not find any answer in the questionnaire that the companies in question employed more than 500 employees. It follows from this fact that this sector is dominated by specialized small-scale production with a focus on quality and manual production with localization on the domestic market. Complete results are shown at figure 2 .

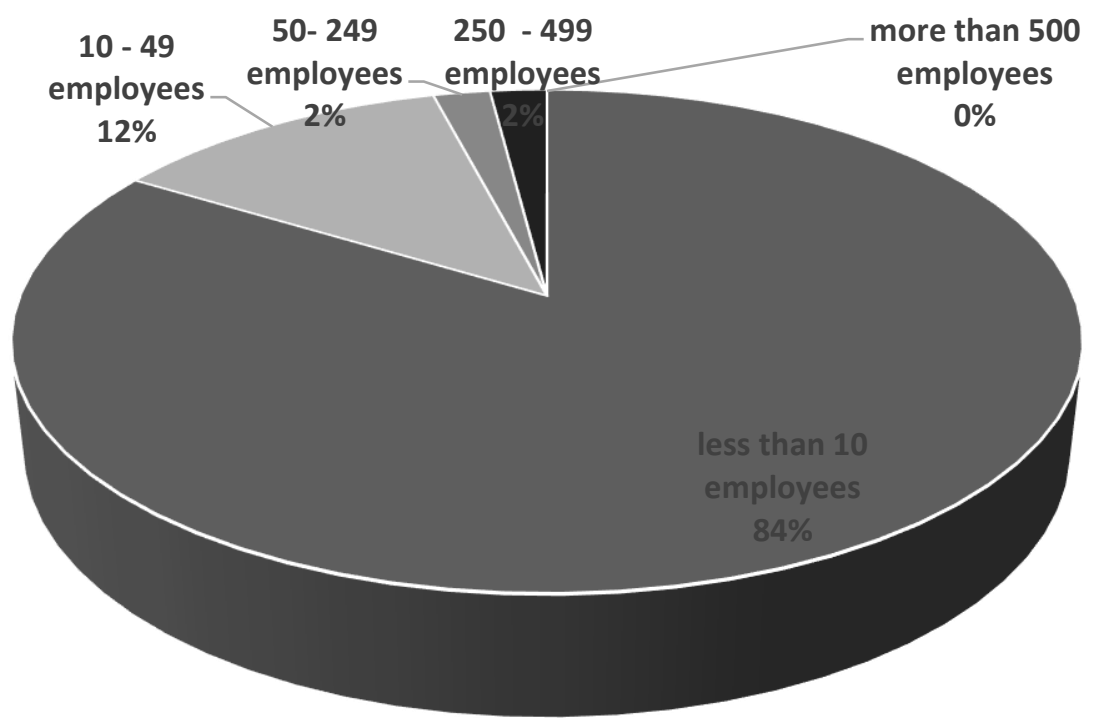

Figure 2. The number of employees in addressed company

Source: Own research

By the third identification question, we found out the length of operation on the market of individual companies. Almost half of the companies have been operating on the market for 6 to 15 years. The second most numerous groups of companies are those that have been operating on the market for 1 to 5 years.

With the question of forms of intellectual property, shown at figure 3, we identified that up to $68.8 \%$ of companies do not apply any protection of industrial rights to their results of creative work. On the other hand, only $23 \%$ of companies use design in their activities and $8 \%$ have trademark protection. 


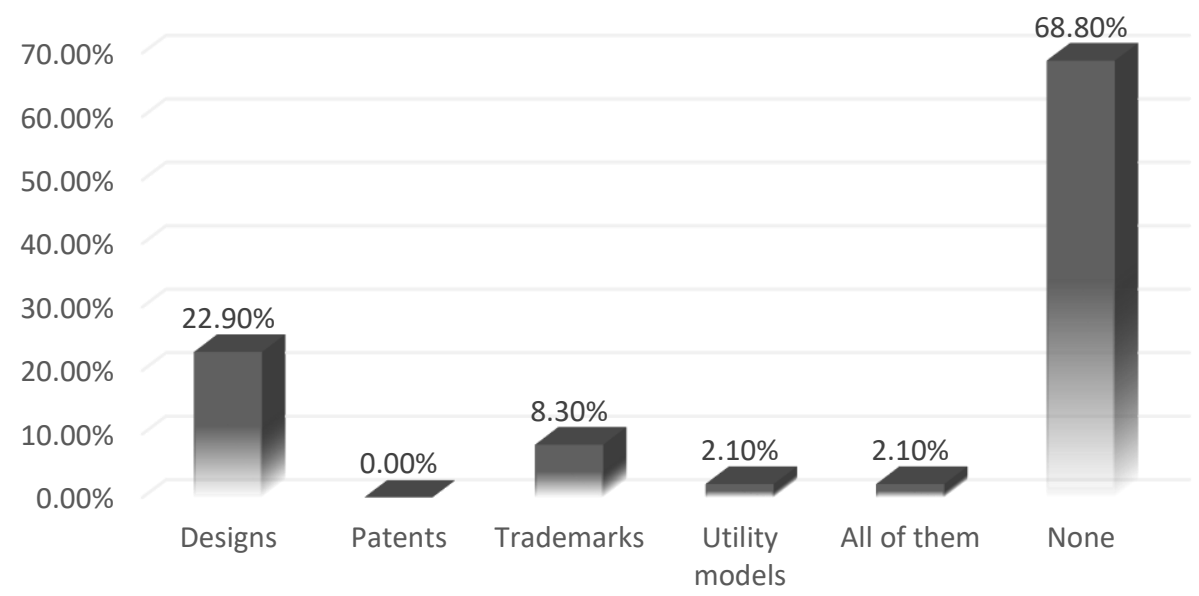

Figure 3. Forms of intellectual property used in selected branch of specialized design activities Source: Own research

As we assumed that intellectual property protection would not be at a high level, we wondered why companies chose not to protect their creative creations through intellectual property rights.

We found that among the basic problems for which companies do not register more industrial property rights are the following:

- a lot of bureaucracy related to the registration of industrial property rights,

- lack of capital for the implementation of intellectual property protection,

- the disparity between the costly investment and the benefits of registered industrial law

- poor legal awareness of the protection of intellectual property not only among people but also among creators, nor do lawyers have sufficient experience in this area of law,

- there is no immediate income from the protection of intellectual property,

- poor law enforcement

According to the questionnaire survey, $68.8 \%$ of companies in the sector of specialized design activities do not apply any protection of industrial rights to their results of creative work. This fact suggests that there is no emphasis on the protection of intellectual property in the sector we are examining. Based on the findings of the questionnaire, here are some recommendations that could help increase activities related to the protection and use of intellectual property rights in this creative sector:

- registration of the brand and related web domains and accounts on social networks. This will prevent businesses from abusing their web domains and accounts, as the industry is based primarily on the visual presentation of products. Many entrepreneurs use social networks to promote their products or services.

- storing and dating the materials of their ideas, which are necessary to enforce registered and unregistered rights, or to defend against allegations of plagiarism.

- apply Fast Track registration mode, which shortens the recording duration.

- filing an application for any subject of industrial law electronically due to the fact that the amount of the administrative fee is lower by $50 \%$ 
- turning to a European grant program to help small and medium-sized enterprises make intellectual property rights more accessible. The scheme allows you to claim a contribution to reimburse $50 \%$ of the costs associated with trademark registration

\section{Conclusion}

There is strong competition in the field of creating creative products or services. It is the protection of the creation of given products and services that helps to prevent mistakes that can often have liquidating consequences for artists. In this paper, we focused on finding out the state of use of the protection of the results of creative activities in the sector of specialized activities. In conclusion, it was found that companies operating in this sector do not pay sufficient attention to the protection of intellectual property, even though they are aware of its importance. For this reason, at the end of the article we proposed Recommendations such as: registering a brand and related web domains and accounts on social networks, storing and dating materials of your ideas, which are necessary for law enforcement, applying an accelerated Fast Track registration regime that shortens registration, filing an application for any subject of industrial law electronically through the portal slovensko.sk in order to save costs for the administrative fee, turn to the European grant program, which aims to help small and medium-sized enterprises to better access intellectual property rights.

\section{Acknowledgements}

This contribution is a partial output of the solution of the project VEGA MŠ SR no. 1/0340/19 "The business dimension of creative industries in the context of innovation and smart growth" in extent $100 \%$.

\section{References}

1. Ministry of Cultur of Slovak republic. (2013). Správa o stave a potenciáli kreatívneho a kultúrneho priemyslu na Slovensku. Available at: https://www.culture.gov.sk/wpcontent/uploads/2020 /02/Podnikatelsky_rozmer_ kulturneho_a_kreativneho_priemyslu.pdf

2. Obnova európy. Kultúrna a kreatívna ekonomika pred a po COVID-19. Available at : https://1761b814-bfb643fc9f9a775d1abca7ab.filesusr.com/ugd/ 4b2ba2_e039b158f0a1465ba6c86f70bb9bd796.pd

3. Kharytonov, E., Kharytonova, O., Tkalych, M., Bolokan, I., Samilo, H., \& Tolmachevska, Y. (2021). Intellectual property law in the field of sports: specifics of manifestations and features of legal regulation. Cuestiones Políticas, 39(69).

4. Lukinović, M., \& Vitosević, Z. (2021). The SARS-COV-2 pandemic and the challenges of intellectual property rights. Srpski arhiv za celokupno lekarstvo, (00), 64-64.

5. Taliashvili, T., \& Shamatava, I. (2020). Recent Evolution of Intellectual Property Enforcement in Georgia. TalTech Journal of European Studies, 10(2), 42-56.

6. Walsh, K., Wallace, A., Pavis, M. et al. (2021). Intellectual Property Rights and Access in Crisis. IIC, 52, 379-416.

7. Majduchova, H. (2019) Duševné vlastníctvo v subjektoch kreatívneho a kultúrneho priemyslu. Available at: https://fpm.euba.sk/www_write/ files/veda-vyskum/zbornikyvedeckych-stati/2019.pdf 
8. Industrial Property Office of The Slovak Republic. (2020). Available at : https://www.indprop.gov .sk/en

9. Barrère, C., \& Delabruyère, S. (2011). Intellectual property rights on creativity and heritage: the case of the fashion industry. European Journal of Law and Economics, 32(3), 305-339.

10. Casey, E., \& O'brien, D. (2020). Sociology, sociology and the cultural and creative industries.

11. Snowball, J., Tarentaal, D., \& Sapsed, J. (2021). Innovation and diversity in the digital cultural and creative industries. Journal of Cultural Economics, 1-29.

12. Imperiale, F., Fasiello, R., \& Adamo, S. (2021). Sustainability Determinants of Cultural and Creative Industries in Peripheral Areas. Journal of Risk and Financial Management, 14(9), 438.

13. Gerlitz, L., \& Prause, G. K. (2021). Cultural and Creative Industries as Innovation and Sustainable Transition Brokers in the Baltic Sea Region: A Strong Tribute to Sustainable Macro-Regional Development. Sustainability, 13(17), 9742.

14. Skujina, R., \& Loots, E. (2020). The intern economy in the cultural industry: an empirical study of the demand side. Journal of Education and Work, 33(5-6), 343-359.

15. European Commission. (2020). Available at : https://ec.europa.eu/futurium/en/jobs-andskills-in-the-local-economy/terms/all/Creative\%20Industries.html 